\title{
Change in antibiotic regimen for emerging multidrug resistance in nosocomial ascitic fluid infection
}

\author{
Seema Alam ${ }^{1}$
}

Received: 31 July 2019 / Accepted: 1 November 2019 / Published online: 21 November 2019

(c) Asian Pacific Association for the Study of the Liver 2019

\section{Graphic abstract}

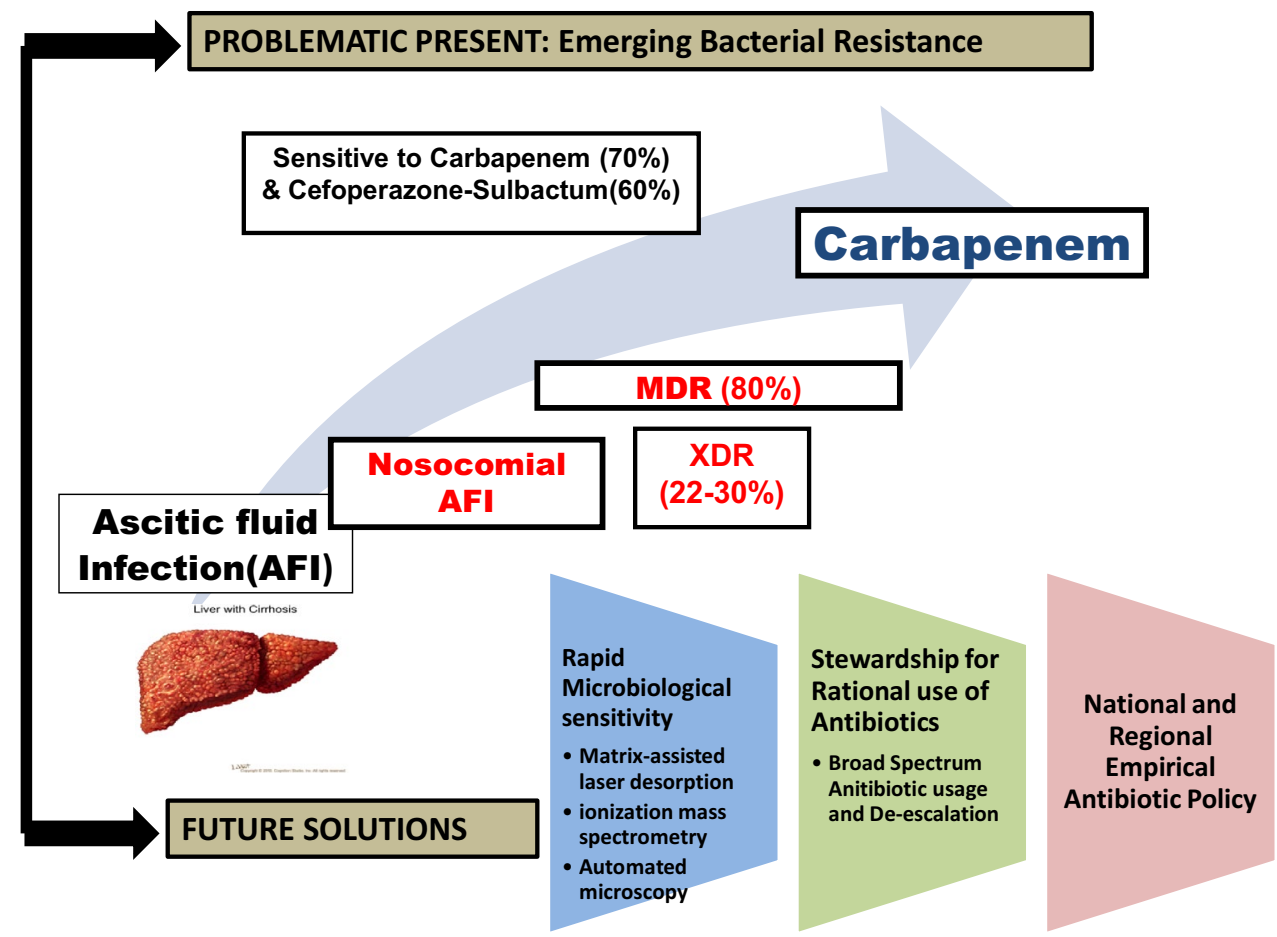

Patients with portal hypertension-related ascites (defined as high serum ascites albumin gradient $>1.1 \mathrm{~g} / \mathrm{dL}$ with 90\% diagnostic accuracy) can develop spontaneous ascitic fluid infections (AFI) without pre-existent intra-abdominal source [1] AFI occurs in 10-30\% of adult cirrhotic patients with ascites in a year's time with in-hospital mortality rate of $20-40 \%$. It has been reported that the risk of dying of some major complications of cirrhosis has decreased over time, but that from sepsis has increased. Increasing spread

Seema Alam

seema_alam@hotmail.com

1 Department of Pediatric Hepatology, Institute of Liver and Biliary Sciences, New Delhi 110070, India of multidrug-resistant (MDR) bacteria and the lack of new effective antibiotics are the likely reasons for this data. A due notice of this has been taken by World Health Organization who adopted an action plan to counteract the MDR strains in the 68th World Health Assembly. International Ascites Club planned a prospective, multicenter cross-sectional study which found the prevalence of MDR bacteria as 34\% in 1302 cirrhotics across the globe and the same for India was $73 \%$ [2].

As per EASL and AASLD guidelines, SBP is diagnosed in patients with liver cirrhosis if polymorphonuclear cell count exceeds 250 cells $/ \mu \mathrm{L}$ in ascetic fluid. It is recommended to initiate prompt antibiotic therapy without awaiting for bacterial culture report. About $50 \%$ of the AFI 
are culture positive and culturing ascitic fluid at bedside increases the sensitivity of the method in approximately $90 \%$. Cases are usually defined as nosocomial if the diagnosis was made either after $48 \mathrm{~h}$ [3] of admission to hospital. The risk of developing AFI is greater in those with coexisting gastrointestinal bleed, previous episode of AFI or low ascitic protein levels as these patients have lower fluid complement levels and opsonin activity In a study, the ascitic fluid protein concentration in the SBP group $(0.72 \pm 0.53 \mathrm{~g} / \mathrm{dL})$ was significantly lower than that seen in patients with sterile portal hypertension-related ascites $(1.36 \pm 0.89 \mathrm{~g} / \mathrm{dL})$ and was significantly lower than that of patients with ascites due to miscellaneous causes. Of those with sterile ascitic fluid protein concentration less than $1.0 \mathrm{~g} / \mathrm{dL}, 15 \%$ developed SBP versus $1.5 \%$ of those whose sterile ascitic fluid protein concentration was greater than $1.0 \mathrm{~g} / \mathrm{dL}$. Hospitalization could also be a risk factor for SBP since SBP and CNNA in asymptomatic patients of outdoor clinic had a combined prevalence of 3.9\%). Oneyear survival of $67 \%$ was better than historical data from hospitalized patients with SBP.

Literature on AFI in children with liver disease is limited, especially in terms of outcome in-hospital, multidrug resistance organisms and follow-up. In this regard the study published in this issue of Hepatology International, by Singh et al. [4] provides much needed data from an Indian tertiary care center about AFI (30\%). The authors report a cohort of 194 predominantly pediatric chronic liver disease with mean age of 85 months. More than half the AFI were nosocomial in origin presenting as fever (60\%), pain in the abdomen (30\%) and diarrhea (7\%) and $40 \%$ were asymptomatic [4]. Most other studies in the Table 1 have reported fever and abdominal pain as the most prevalent clinical features of AFI [serial number $3,4,7,10,11$ ). In a report in 2017 , from the same center as Singh et al. a total of $28.6 \%$ children with liver disease-related ascites had SBP/CNNA (serial number 4). The prevalence of this Indian centre is comparable to that reported from elsewhere: varying between 28 and $43 \%$ in children with portal hypertensive ascites and/or endstage chronic liver disease (serial number $3,4,7,11$ ). The prevalence of SBP decreased in Brazil from 29.06 to $13 \%$ in a decade (serial number 10 and 6), whereas around a decade back in Iran the prevalence varied between 20.06 and $36 \%$ in similar studies (serial number 8 and 9) and is $27.3 \%$ now (serial number 5). Signs of advanced liver disease such as low albumin, prolonged disease, cirrhosis, high Child-Pugh score and hepatic encephalopathy indicated higher likelihood of AFI as reported by Singh et al. [4] and others before (serial number 4,6,10). Elevated absolute neutrophil count and positive $\mathrm{C}$ reactive protein were also found to be good indicators of AFI (serial number 3 and 5). It has also been reported that total white cell count declined to $30 \%$, neutrophil count reduced to half and ascitic fluid cultures became negative after $48 \mathrm{~h}$ of antibiotic therapy (serial number 9).

In the study by Singh et al. [4], $40 \%$ of the children with chronic liver disease and AFI died in hospital and 7\% had a 1-year AFI recurrence. Chronic liver disease with SBP was similar to CNNA except for higher in-hospital mortality. Area under ROC curve (AUC $=0.72$ ) showed that Child-Pugh score cut-off 11 had $65 \%$ sensitivity and $71 \%$ specificity to determine in-hospital mortality [4]. Other studies have reported mortality of $25 \%$ and $40 \%$, respectively, associated with AFI and SBP, respectively (serial number 4, 7). In a Brazilian study, the cumulative probability of native liver survival was $77.8 \%$ at 1 month, $27.8 \%$ at 3 months, and $11.1 \%$ at 6 months following the first episode of SBP resulting in mortality in $60 \%$ and liver transplant in $39 \%$ within a year (serial number 3). AFI follows an episode of bacteremia due to the constant exchange of fluids between the peritoneal and intravascular space. Bacterascites represents the transitory passage of bacteria through the ascitic fluid before lysis resulting from the bactericidal activity of ascites. So some patients may have bacterascites and later develop SBP. But it has also been suggested that the complement deficiency induced by chronic liver disease may be important in the pathogenesis of SBP. There should be immediate initiation of antibiotic treatment after AFI is diagnosed and so, a good knowledge of the local pathogens in the various centers as well as their sensitivity pattern is required. As is evident from table, most episodes of SBP are monomicrobial and due to Gram-negative bacteria, Escherichia coli being the most frequently isolated organism. Other frequently isolated bacteria include Klebsiella, Pseudomonas aeruginosa, methicillin-resistant Staphylococcus aureus, S. pneumoniae and Enterococci (table). Some workers have suggested that pneumococcal vaccination may have a role to play in the prevention of SBP in children (serial number 9). In the light of the emergence of MDR bacteria as causative agents of AFI, it is imperative to relook at the first-line antibiotics. The present study by Singh et al. is the first pediatric study to report that $83 \%$ of the Gram-negative organisms causing AFI were MDR and $80 \%$ of these were nosocomial infections [4]. Similar results have been reported by a global study for isolates from Indian centers [2]. Moreover, in this global report, extensively drug-resistant (XDR) bacteria, which are defined as nonsusceptibility to at least 1 agent in all but less than 2 antimicrobial categories, were present in 33\% of isolates from India as compared to other countries ( $0-16 \%$ isolates). Sensitivity to cefoperazone-sulbactam and carbapenem was present in $60 \%$ and $70 \%$, respectively, in the present study by Singh et al. [4] which means that $30 \%$ of the isolates were carbapenem-resistant and these figures are comparable with the $22 \%$ XDR reported by the global study [2] for the isolates from India [2]. On univariate analysis, Singh et al. 
Table 1 Studies done in childhood chronic liver disease with ascitic fluid infection

\begin{tabular}{|c|c|c|c|c|c|c|c|c|c|}
\hline Serial no & $\begin{array}{l}\text { Study year and journal } \\
\text { references }\end{array}$ & Sample size & $\begin{array}{l}\text { Median } \\
\text { age } \\
\text { (years) }\end{array}$ & $\begin{array}{l}\text { Prevalence } \\
(\%)\end{array}$ & Risk factors & $\begin{array}{l}\text { Death } \\
(\%)\end{array}$ & Gram -ve & Gram +ve & MDR \\
\hline 1 & $\begin{array}{l}\text { Singh } 2019 \text { India. Hepatol } \\
\text { Int. 2019 Jul 9. https:// } \\
\text { doi.org/10.1007/s1207 } \\
\text { 2-019-09968-x }\end{array}$ & 193 & 7 & 31 & $\begin{array}{l}\text { Longer } \\
\text { duration of } \\
\text { illness } \\
\text { Higher CTP } \\
\text { score }\end{array}$ & 40 & $\begin{array}{l}\text { E. coli } 38 \% \\
\text { Klebseilla } \\
10 \% \\
\text { Acinobacter } \\
5 \%\end{array}$ & $\begin{array}{l}\text { CONS } 14 \% \\
\text { S. pneumo- } \\
\text { niae } 10 \% \\
\text { S. fecalis } \\
\quad 10 \%\end{array}$ & $\begin{array}{l}83 \% \text { of Gram } \\
\text {-ve }\end{array}$ \\
\hline 2 & $\begin{array}{l}\text { Ghobrial 2018 Egypt } \\
\text { PLoS One. } 2018 \text { Oct } \\
\text { 5;13(10):e0203808 }\end{array}$ & 66 & 1 & 33 & $\begin{array}{l}\text { Fever, } \\
\text { abdominal } \\
\text { pain ANC } \\
\text { and posi- } \\
\text { tive CRP }\end{array}$ & ND & $\begin{array}{l}\text { E. coli } 20 \% \\
\text { Kebseilla } \\
20 \% \\
\text { Pseu- } \\
\text { domonas } \\
10 \%\end{array}$ & $\begin{array}{l}\text { S. aureus } \\
50 \% \\
\text { S. viridians } \\
10 \% \\
\text { Acinobacter } \\
10 \% \\
\text { S fecalis } \\
10 \%\end{array}$ & ND \\
\hline 3 & $\begin{array}{l}\text { Veira } 2018 \text { Brazil Eur J } \\
\text { Gastroenterol Hepatol. } \\
2018 \text { Mar; 30(3):323- } \\
327\end{array}$ & 18 & 1 & ND & ND & 60 & $\begin{array}{l}\text { E. coli } 44 \% \\
\text { Klebseilla } \\
22 \%\end{array}$ & $\begin{array}{l}\text { S. virirdans } \\
11 \% \\
\text { Staph } \\
\text { aureus }\end{array}$ & Nil \\
\hline 4 & $\begin{array}{l}\text { Srivastava } 2017 \text { India } \\
\text { J Pediatr Gastroen- } \\
\text { terol Nutr. } 2017 \\
\text { Feb;64(2):194-199 }\end{array}$ & 262 & 7 & 28.6 & $\begin{array}{l}\text { Higher } \\
\text { WBC } \\
\text { HE } \\
\text { Bacteremia }\end{array}$ & 31.8 & $\begin{array}{l}\text { E. coli } 37 \% \\
\text { Klebseilla } \\
14.8 \%\end{array}$ & $\begin{array}{l}\text { CONS } \\
14.8 \% \\
\text { S. fecalis } \\
3.1 \%\end{array}$ & ND \\
\hline 5 & $\begin{array}{l}\text { Kalvandi } 2016 \text { Iran. } \\
\text { Hepat Mon. } 2016 \text { Jul } \\
\text { 23;16(8):e38973 }\end{array}$ & 150 & 4.7 & 27.3 & CRP & ND & $\begin{array}{l}\text { E. coli } 41 \% \\
\text { Klebseilla } \\
11 \% \\
\text { Acinobacter } \\
11 \%\end{array}$ & $\begin{array}{l}\text { S. pneumo- } \\
\text { niae } 11 \% \\
\text { Enterococ- } \\
\text { cus } 18 \%\end{array}$ & ND \\
\hline 6 & $\begin{array}{l}\text { Preto-Zamperlini } 2014 \\
\text { Brazil J Pediatr Gas- } \\
\text { troenterol Nutr. } 2014 \\
\text { Jan;58(1):96-98 }\end{array}$ & 152 & $2-18$ & 13 & $\begin{array}{l}\text { CRP } \\
\text { Lower albu- } \\
\text { min High } \\
\text { WBC } \\
\text { prolonged } \\
\text { PT }\end{array}$ & ND & $\begin{array}{l}\text { Haemo- } \\
\text { philus } \\
\text { influenza } \\
\text { Bacteroides }\end{array}$ & $\begin{array}{l}\text { S. pneumo- } \\
\text { niae } 44 \%\end{array}$ & ND \\
\hline 7 & $\begin{array}{l}\text { El-Shabrawi } 2011 \\
\text { Egypt Italian J Pediatr } \\
\text { 2011;37(1):26-29 }\end{array}$ & 30 & 5.1 & 43 & $\begin{array}{l}\mathrm{pH} \text { gradient } \\
\text { at a cut } \\
\text { off } \geq 0.1\end{array}$ & 23 & $\begin{array}{l}\text { Bacteroides } \\
\quad(40 \%),\end{array}$ & $\begin{array}{l}\text { S aureus } \\
\text { (20\%), } \\
\text { Strepto- } \\
\text { coccus } \\
(40 \%)\end{array}$ & ND \\
\hline 8 & $\begin{array}{l}\text { Deghani } 2007 \text { Iran Pediatr } \\
\text { Transplant. 2007;11:21- } \\
23\end{array}$ & 83 & $8+5.1$ & 36.1 & ND & ND & ND & ND & ND \\
\hline 9 & $\begin{array}{l}\text { Haghighat } 2006 \text { Iran } \\
\text { World J Gastroenet- } \\
\text { rol. 2006;12(36):5890- } \\
5892\end{array}$ & 63 & 5.5 & 20.6 & ND & 8 & E. coli $15 \%$ & $\begin{array}{l}\text { S. pneu- } \\
\quad \text { moniae } \\
38.5 \% \\
\text { S viridans } \\
15 \%\end{array}$ & $0 \%$ \\
\hline 10 & $\begin{array}{l}\text { Veira } 2005 \text { Brazil J Pediatr } \\
\text { Gastroenterol Nutr.2005 } \\
\text { Mar;40(3):289-94 }\end{array}$ & 41 & 5.2 & 29.2 & $\begin{array}{l}\text { Cirrhosis } \\
\text { Low albu- } \\
\text { min }\end{array}$ & ND & $\begin{array}{l}\text { Klebsiella, } \\
\text { E coli and } \\
\text { Salmo- } \\
\text { nella }\end{array}$ & S. aureus & ND \\
\hline 11 & $\begin{array}{l}\text { Larcher } 1985 \text { J Pediatr. } \\
1985 \text { Jun; 106(6):907-12 }\end{array}$ & 11 & - & ND & ND & ND & Klebsiella, & $\begin{array}{l}\text { S. pneumo- } \\
\text { niae } 80 \%\end{array}$ & ND \\
\hline
\end{tabular}

MDR multi drug resistance, $C P T$ score Child Turcotte Pugh score, CRP C reactive protein, $N D$ not described, ANC absolute neutrophil count, WBS white blood cell, PT prothrombin time, E. coli Escherichia coli, CONS coagulase negative Staphylococcus, S. pneumoniae Streptococcus pneumoniae, S. fecalis Streptococcus fecalis, S. viridians Streptococcus viridans 
[4] found that the nosocomial acquisition of infection and history of antibiotics exposure prior to the index admission were significantly associated with development of antibiotics resistance. On multivariate analysis, history of antibiotics exposure independently predicted the development of resistant organism in AFI [OR (95\% CI): 15.7 (1.42-174.20); $p=0.025$ ] [4]. Independent risk factors for MDR bacteria were infection in Asia (particularly in India), use of antibiotics in the 3 months before hospitalization and prior health care exposure in the global study [2]. Fernandez et al. in their hallmark work report that nosocomial origin, norfloxacin prophylaxis, previous infection with MDR bacteria and use of beta-lactams were risk factors for new MDR infections, treatment failure and poor survival in their cohort of decompensated cirrhosis among adults [5]. There have been many reports from across the world as well as India about emergence of MDR bacteria as a causative agent of AFI [2, 5]. The alarming increase in usage of injudicious antibiotic and the emergence of MDR isolates, emphasizes on careful use of antibiotics and an urgent need for early detection of these isolates for better treatment outcome.

The increasing emergence of MDR pathogens is causing the failure of traditional treatment regimens for nosocomial SBP, namely third-generation cephalosporins. According to the recent recommendations, third-generation cephalosporins should be restricted only to selected patients, particularly in case of community-acquired infections [6]. Singh et al. [4] suggested use of cefoperazone-sulbactam or carbapenems as first line of antibiotics in children with nosocomial AFI. Two recent studies showed that cefoperazone/sulbactam had a lower success rate and a higher 14-day mortality rate compared with carbapenems in bloodstream infections due to extended spectrum beta-lactamase producing Enterobacteriaceae [7, 8]. Hence cefoperazone/sulbactam could be considered as empirical therapy in less severe patients with nosocomial infections or as definitive therapy when antimicrobial susceptibility test is available. But the severe nosocomial infections should be treated with carbapenems as the first line of therapy. Finally, children with CLD and AFI should be listed for early liver transplantation to improve their survival. For insight into future strategies please see the graphical abstract.

\section{Compliance with ethical standards}

Conflict of interest I have no conflict of interest to declare.

\section{References}

1. Runyon BA, AASLD Practice Guidelines Committee. Management of adult patients with ascites due to cirrhosis: an update. Hepatology 2009;49:2087-2107

2. Piano S, Singh V, Caraceni P, Maiwall R, Alessandria C, Fernandez J, International Club of Ascites Global Study Group, et al. Epidemiology and effects of bacterial infections in patients with cirrhosis worldwide. Gastroenterology 2019;156(5):1368. e10-1380.e10

3. Alexopoulou A, Vasilieva L, Agiasotelli D, Siranidi K, Pouriki S, Tsiriga A, et al. Extensively drug-resistant bacteria are an independent predictive factor of mortality in 130 patients with spontaneous bacterial peritonitis or spontaneous bacteremia. World J Gastroenterol 2016;22:4049-4056

4. Singh SK, Poddar U, Mishra R, Srivastava A, Yachha SK. Ascitic fluid infection in children with liver disease: time to change empiricalantibiotic policy. Hepatol Int 2019;9:45. https://doi. org/10.1007/s12072-019-09968-x (Epub ahead of print)

5. Fernández J, Acevedo J, Castro M, Garcia O, de Lope CR, Roca $\mathrm{D}$, et al. Prevalence and risk factors of infections by multiresistant bacteria in cirrhosis: a prospective study. Hepatology 2012;55(5):1551-1561

6. Piano S, Fasolato S, Salinas F, Romano A, Tonon M, Morando $\mathrm{F}$, et al. The empirical antibiotic treatment of nosocomial spontaneous bacterial peritonitis: results of a randomized, controlled clinical trial. Hepatology 2016;63:1299-1309

7. Su J, Guo Q, Li Y, Wu S, Hu F, Xu S, et al. Comparison of empirical therapy with cefoperazone/sulbactam or a carbapenem for bloodstream infections due to ESBL-producing Enterobacteriaceae. J Antimicrob Chemother 2018;73(11):3176-3180

8. MERINO Trial Investigators and the Australasian Society for Infectious Disease Clinical Research Network (ASID-CRN). Effect of piperacillin-tazobactam vs meropenem on 30-day mortality for patients with E coli or Klebsiella pneumoniae bloodstream infection and ceftriaxone resistance: a randomized clinical trial. JAMA 2018;320(10):984-994

Publisher's Note Springer Nature remains neutral with regard to jurisdictional claims in published maps and institutional affiliations. 